\title{
Adoption of On-Farm Plantation Forestry by Smallholder Farmers in Uganda
}

\author{
I. Kiyingi ${ }^{1,2}$, A. Edriss ${ }^{2}$, M. Phiri ${ }^{2}$, M. Buyinza ${ }^{3} \&$ H. Agaba ${ }^{1}$ \\ ${ }^{1}$ National Forestry Resources Research Institute, NaFORRI, P.O Box 1752, Kampala, Uganda \\ ${ }^{2}$ Department of Agricultural And Applied Economics, Faculty Of Development Studies, Lilongwe Univeristy Of \\ Agriculture And Natural Resources, Malawi \\ ${ }^{3}$ School of Postgraduate Studies, Makerere University, P.O. Box 7062, Kampala, Uganda \\ Correspondence: Isaac Kiyingi, National Forestry Resources Research Institute, NaFORRI, P.O Box 1752, \\ Kampala, Uganda. Tel: 256-75-295-9870. E-mail: ikiyingi_2000@yahoo.com
}

Received: December 4, 2015

Accepted: January 3, 2016 Online Published: March 30, 2016

doi:10.5539/jsd.v9n2p153

URL: http://dx.doi.org/10.5539/jsd.v9n2p153

\begin{abstract}
The study assessed the factors influencing adoption and intensity of adoption of on-farm plantation forestry by comparing results from a censored Tobit model and a Double-hurdle model. Analysis indicated that determinants of adoption and intensity of adoption of on-farm plantation forestry are different, thus indicating a double-hurdle process. Results from the double-hurdle model indicated that size of landholding, secondary school education, forestry skills training, extension services and farmers' perceptions significantly explain the variation in the decision to invest in on-farm plantation forestry. On the other hand, gender of household head and size of landholding influenced the intensity of adoption. This study highlights some of the areas that should be considered in developing adoption strategies for on-farm plantation forestry. It also highlights the importance of farmers' perceptions in influencing adoption of farm forestry. The study suggests that since the factors influencing adoption and intensity of farm forestry adoption are made separately, it is important that both stages are considered in developing adoption strategies for farm forestry.
\end{abstract}

Keywords: adoption, double-hurdle, on-farm, plantation forestry, Tobit

\section{Introduction}

The Ugandan government and international donors have promoted on-farm plantation forestry through projects such as Farm Income Enhancement and Forest Conservation Project (FIEFOC), National Agricultural Advisory Services (NAADS) and Sawlog Production Grant Scheme (Kaboggoza, 2011). The key objectives of government support to farm forestry were to alleviate high rural poverty, increase food security and address the high deforestation rate (Ministry of Water, Lands and Environment [MWLE], 2001; MWLE, 2002; SPGS, 2005). The assumption is that facilitating poor households to participate in farm forestry would improve their incomes and enable them to eventually escape poverty by producing products and services for home consumption as well as cash income. Except for a few districts in south western Uganda, the adoption of on-farm plantation forestry is still low in many parts of the country (Kaboggoza, 2011; Sawlog Production Grant Scheme [SPGS], 2005). Therefore, identification of the factors determining adoption of on-farm plantation forestry is expected to improve the effectiveness of extension services and farm forestry policy. Specifically, the study results can be used to develop a more efficient on-farm plantation forestry adoption strategy. This is important given the fact that 22.8 percent of rural households in Uganda still suffer from absolute poverty (Ministry of Finance, Planning and Economic Development [MFPED], 2014)

Several studies have assessed the factors influencing adoption of farm forestry in developing countries (Adesina et al., 2000; Oeba et al., 2012; Tiwari et al., 2008; Bayard et al., 2007). These studies reported that adoption was influenced by demographic, socio-economic, institutional and farm characteristics such as contact with extension agencies, belonging to farmer's groups, population pressure, fuel wood scarcity, tree tenure security, size of land holding, education level, soil erosion index and gender. However, few studies (Buyinza et al., 2008) have specifically analyzed the factors influencing adoption of on-farm plantation forestry in Uganda. To our knowledge, none of these studies has analyzed the factors influencing the intensity of adoption after the adoption 
decision has been made. The few studies also did not assess how farmers' perceptions of technology attributes influence the adoption decision. The paucity of empirical evidence on the factors influencing adoption and intensity of adoption of on-farm plantation forestry and the role of farmers' perceptions, justifies further investigation. Therefore, this study identified the perception, socioeconomic and institutional factors that influence the adoption and intensity of on-farm plantation forestry in south western Uganda.

\section{Methods}

\subsection{Data Collection}

The study was conducted in the districts of Rubirizi and Mitooma in south western Uganda. The districts were purposively sampled because they have a relatively high adoption rate of on-farm plantation forestry. Stratified cluster random sampling was used to select 960 respondents from the two districts. A household questionnaire survey was used to collect data on demographic, perception, socioeconomic and institutional characteristics of respondents. Questionnaire survey data was supplemented by qualitative data collected through key informant interviews and focus group discussions.

\subsection{Theoretical Framework}

The proportion of land allocated to on-farm plantation forestry represents a censored distribution since some farmers would assume a value of zero for not adopting (non-users). Accordingly, there is a cluster of households with zero proportion of land allocated to farm forestry at the limit. The censored Tobit model depends on the assumption that the factors that influence a farmers decision to adopt farm forestry also increase the intensity of adoption (Lin \& Schmidt 1984; Kachova \& Miranda 2004). Other researchers have relaxed the assumption inherent in the joint Tobit model by specifying a Double-Hurdle model in which the adoption and determination of the level of intensity of application are seen as a two-step procedure (Cragg, 1971). The first involves making the decision to adopt and the second involves deciding on the extent of adoption (Staal et al., 2002; Shiyani et al., 2002; Wabbi et al., 2006). Therefore, assessment of the factors influencing adoption and the intensity of adoption of on-farm plantations was estimated by comparing results from a censored Tobit model (Feder et al., 1985; Freeman \& Omiti, 2003) and a Double-Hurdle model (Cragg, 1971) using the likelihood ratio test.

To model the influence of farmers' perceptions on intensity of plantation forestry adoption, the study followed Adesina and Baidu-Forson (1995) and considered that a smallholder farmer i perceives to obtain a benefit $\pi(\mathrm{c})$ from adopting on-farm plantation forestry and $\mathrm{Z}(\mathrm{t})$ from not adopting. The smallholder farmer is assumed to have perceptions of on-farm plantation forestry characteristics and let the perceptions be represented by $\mathrm{M}_{\mathrm{ic}}$ and $\mathrm{P}_{\mathrm{it}}$ for adoption and non-adoption respectively. Let socio-economic and demographic factors be represented by R. Let $\pi_{c i}=f\left(M_{i c}, P_{i t} ; R_{i}\right)$ and $Z_{t i}=g\left(M_{i c}, P_{i t} ; R_{i}\right)$. Let the difference between the perceived benefit from adoption $\pi_{\mathrm{i}}(\mathrm{c})$ and non-adoption $\mathrm{Z}_{\mathrm{i}}(\mathrm{t})$ of farm forestry be denoted as $S_{h}^{*}$ and represented as:

$$
S_{h}^{*}=\pi_{\mathrm{i}}(\mathrm{c})-\mathrm{Z}_{\mathrm{i}}(\mathrm{t})
$$

If the participation decision $\mathrm{J}=1$ for participants and 0 otherwise, the link between the binary decision variable and the latent variable $S_{h}^{*}$ will be expressed as.

$$
J=\left\{\begin{array}{l}
1 \text { if } S_{h}^{*} \geq 0 \\
0 \text { if } S_{h}^{*}<0
\end{array}\right.
$$

The above equation implies that households will only participate in farm forestry if the perceived benefit from participation is positive.

A Tobit model will be used to estimate the determinants of adoption and intensity of adoption of farm forestry (Tobin, 1958), represented as

$$
\begin{gathered}
A_{i}^{*}=\beta x_{i}+\varepsilon_{i} \\
A_{i}=0 \text { if } A_{i}^{*} \leq 0 \\
A_{i}=A_{i}^{*} \text { if } A_{i}^{*}>0
\end{gathered}
$$

Where $\mathrm{A}_{\mathrm{i}}$ represents the proportion of land allocated to on-farm plantation forestry (observable variable); $A_{i}^{*}$ is the latent variable that indexes the adoption of on-farm plantation forestry intervention; $x$ is a vector of perception and socio-economic variables; $\beta$ is a vector of parameters to be estimated (Tobit maximum likelihood estimates); and $\varepsilon$ is the independently and normally distributed error term assumed to be normal with mean zero 
and constant variance $\sigma$.

The Tobit model is estimated by maximum likelihood estimation (Tobin, 1958). The likelihood function consists of two parts. For the adopters, $A_{i}=A_{i}^{*}$, this part is given by the density function as

$$
\frac{1}{\sigma} \phi\left[\frac{A_{i}-\beta x_{i}}{\sigma}\right]
$$

For the non-adopters, $A^{*} \leq 0$, the likelihood contribution is given by

$$
1-\Phi\left(\frac{\beta x_{i}}{\sigma}\right)
$$

Where, $\phi($.$) and \Phi($.$) are the probability density and standard normal cumulative distribution functions,$ respectively. The likelihood function is represented as

$$
L=\prod_{A_{i}=0}\left[1-\Phi\left(\frac{\beta x_{i}}{\sigma}\right)\right] \prod_{A_{i}>0} \frac{1}{\sigma} \phi\left(\frac{A_{i}-\beta x_{i}}{\sigma}\right)
$$

The Tobit estimators of the parameters are the $\beta$ and $\sigma$ values which maximize the likelihood function $(\mathrm{L})$. The marginal effect of an explanatory variable on the expected value of $A$ is:

$$
\frac{\partial E(A \mid x)}{\partial x_{k}}=\beta_{k} \Phi\left(\frac{\beta x}{\sigma}\right)
$$

The marginal effect of an explanatory variable on A for the adopters is:

$$
\frac{\partial E(A \mid x, A>0)}{\partial x_{k}}=\beta\left\{1-\lambda\left(\frac{\beta x}{\sigma}\right)\left[\frac{\beta x}{\sigma}+\lambda\left(\frac{\beta x}{\sigma}\right)\right]\right\}
$$

Where $\lambda(c) \equiv \frac{\phi(c)}{\Phi(c)}$ is the inverse mills ratio.

\subsubsection{Double-Hurdle Model}

It has been observed that the decision to adopt might in fact precede that on intensity of adoption. Following Cragg (1971) and Moffat (2003), the Double-Hurdle model contains two equations. The first stage of Cragg's model is a probit model to analyze determinants of adoption, and the second stage is a truncated regression model for determinants of the level of adoption (Cragg, 1971).

Where

$$
\begin{aligned}
& d_{i}^{*}=\alpha z_{i}+\mu_{i} \\
& y_{i}^{*}=\beta x_{i}+\varepsilon_{i}
\end{aligned}
$$

$$
d_{i}=\left\{\begin{array}{l}
1, \text { if } d_{i}^{*}>0 \\
0, \text { if } d_{i}^{*} \leq 0
\end{array} \quad \text { and } \quad y_{i}=\left\{\begin{array}{l}
y_{i}^{*}, \text { if } y_{i}^{*}>0 \text { and } d_{i}^{*}>0 \\
0 \text { if } \text { otherwise }
\end{array}\right\}\right.
$$

Where, $d_{i}{ }^{*}$ is the latent variable describing a farm's decision to adopt on-farm plantation forestry, taking on value of 1 if the farmer adopts or 0 if farmer does not adopt. $y_{i}{ }^{*}$ is the latent variable describing its decision on the proportion of land to allocate to on-farm plantation forestry, and $d_{i}$ and $y_{i}$ are their observed counterparts, respectively. $\boldsymbol{z}_{i}$ is the vector of variables explaining whether a farmer adopts farm forestry, $\boldsymbol{x}_{i}$ is a vector of variables explaining level of adoption, and $\mu_{i}$ and $\varepsilon_{i}$ are the error terms. Equations 1 and 2 are assumed to be independent, and therefore the error terms are randomly and independently distributed, $\varepsilon_{i} \sim N(0,1)$ and $\mu_{i} \sim$ $N\left(0, \sigma_{\varepsilon}^{2}\right)$ (Caroll et al., 2005). Under this assumption, the likelihood function is the sum of the truncated regression and the Probit models and is given as:

$$
L=\prod_{y_{i}=0}\left[1-\Phi\left(z_{i} \alpha\right) \Phi\left(\frac{x_{i} \beta}{\sigma}\right)\right]+\prod_{y_{i}>0}\left(\Phi\left(z_{i} \alpha\right) \frac{1}{\sigma} \emptyset\left(\frac{y_{i}-x_{i} \beta}{\sigma}\right)\right)
$$

where $\Phi$ and $\phi$ are the standard normal cumulative distribution function and density function, respectively. The log-likelihood function is estimated using the maximum likelihood estimation (MLE) technique.

The two models can be compared using the likelihood ratio test when the determinants in both hurdles are the same (Greene, 2000). The LR statistics can be computed using the following formula:

$$
\Gamma=-2\left[\ln L_{T}-\left(\ln L_{P}+\ln L_{T R}\right)\right] \sim x_{k}^{2}
$$


Where $L_{T}, L_{P}$, and $L_{T R}$ are log-likelihoods of the Tobit, Probit, and truncated regression models, respectively, and $\mathrm{k}$ is the number of independent variables in both equations. The likelihood ratio test involves testing the hypothesis that $\lambda=\frac{\beta}{\sigma}$. The null hypothesis will be rejected if $\left(\Gamma>x^{2}\right)$. Rejection of the null hypothesis indicates the superiority of the double-hurdle model over the Tobit model and establishes that the decisions about adoption and level of adoption are made in two different stages.

\subsection{Empirical Model}

The dependent variable in the first stage of the double-hurdle model is the farmer's adoption decision. This variable is binary in nature, taking numeric value 1 for adopters, and 0 for non-adopters. In the second stage, the dependent variable is the proportion of farm land allocated to on-farm plantation forestry. As the variables explaining adoption can also explain level of adoption, the same set of independent variables were used in both stages. The dependent variable for the Tobit model is also the proportion of farm land allocated to on-farm plantation forestry.

The proportion of farm land allocated to on-farm plantation forestry or adoption decision $(\mathrm{Y})$ is specified as a function of perception, socio-economic and institutional factors as follows:

$$
Y_{i}=\beta_{0}+\beta_{j} X_{i j}+\mu_{i}
$$

The key variables investigated in this study include a set of perception variables (Perceived compatibility with agricultural crop production, labour requirements, expected returns, initial investment, time to accrue benefits, ability to provide income during hunger periods), socio-economic (age of household head, education, gender, farming experience, non-farm employment, non-farm income, distance to market) and institutional variables (extension services, forestry skills training, security of tenure). Variable selection was based on variables used in other plantation forestry adoption studies.

Perceptions were measured by asking farmers to rate the attributes of on-farm plantation forestry. Each dummy variable for perceptions of on-farm plantation forestry attributes was coded as 1 if the respondent stated that the given characteristic was a positive characteristic of on-farm plantation forestry, and 0 otherwise.

Table 1. Description of variables specified in the model

\begin{tabular}{|c|c|c|}
\hline Variable & Variable description & Variable measurement \\
\hline Woodlot & Woodlot adoption & Dummy (1=adopt, 0 otherwise) \\
\hline Intensity & intensity of adoption & $\begin{array}{l}\text { Proportion of farm land allocated to on-farm } \\
\text { plantation forestry }\end{array}$ \\
\hline Agricultural crops & $\begin{array}{l}\text { Perceived compatibility of on-farm plantation } \\
\text { forestry with agricultural crop production. }\end{array}$ & Dummy (1=positive, 0 otherwise) \\
\hline Perceived returns & Perceived returns from farm forestry & Dummy (1=positive, 0 otherwise) \\
\hline income & $\begin{array}{l}\text { Perceived ability to provide out of crop season } \\
\text { income }\end{array}$ & Dummy (1=positive, 0 otherwise) \\
\hline Landsize & Household landholding & Acres \\
\hline Age & Age of household head & Years \\
\hline Security of tenure & Security of land tenure & Dummy $(1=$ secure, 0 otherwise $)$ \\
\hline Female headed & Female headed household & Dummy( $1=$ female, 0 otherwise $)$ \\
\hline Secondary & Secondary education by household head & $\operatorname{Dummy}(1=$ secondary, 0 otherwise $)$ \\
\hline Tertiary & Tertiary education by household head & Dummy(1=Tertiary, 0 otherwise $)$ \\
\hline Forestry skills & Received formal forestry skills training & Dummy ( $1=$ trained, 0 otherwise $)$ \\
\hline Experience & Years of farming experience & Years \\
\hline One extension & Atleast one extension visit in last year & $\operatorname{Dummy}(1=$ received, 0 otherwise $)$ \\
\hline Two extension & Atleast two extension visits in last year & $\operatorname{Dummy}(1=$ received, 0 otherwise $)$ \\
\hline Employment & Formal employment by household head & Dummy(1=employed, 0 otherwise $)$ \\
\hline Non-farm & Non-farm income by household & Dummy ( $1=$ income, 0 otherwise $)$ \\
\hline Distance & Distance to main market & Kilometres \\
\hline
\end{tabular}




\section{Results and Discussion}

Comparison of the two models using the likelihood ratio test indicated the superiority of the double-hurdle model over the Tobit model. The likelihood ratio statistic $(\Gamma=284.72)$ exceeded the critical value $(\chi 2(16)=26.29)$ at the $5 \%$ level of significance. This implies that the decisions about adoption and proportion of land allocated to farm forestry were made in two different stages. Consequently, the discussion focuses on the results of the double-hurdle model.

Literature indicates that violation of the assumptions of homoscedastic and normally-distributed errors leads to inconsistent maximum likelihood parameter estimates (Fennema \& Sinning, 2007; Martinez-Espineira, 2006). Thus, the regressions were estimated using robust standard errors to correct for heteroscedasticity. To get a normally distributed error term, the dependent variable was transformed to the square root of the proportion of land allocated to farm forestry. The VIF was less than 10 indicating the absence of problems of multicollinearity.

The Wald test of joint significance of the joint Tobit and double-hurdle models, with a chi-square distribution is highly significant at $1 \%$ level indicating that the chosen independent variables fit the data reasonably well (Table 2). The results for both the joint Tobit and Double-Hurdle model are presented in Table 2.

Table 2. Maximum likelihood estimates for joint Tobit and Hurdle models

\begin{tabular}{|c|c|c|c|c|c|c|}
\hline \multirow[t]{3}{*}{ Variable } & \multirow{3}{*}{$\begin{array}{l}\text { Joint Tobit } \\
\text { estimates }\end{array}$} & \multicolumn{5}{|c|}{ Double-hurdle estimates } \\
\hline & & \multicolumn{3}{|c|}{ Probit } & \multicolumn{2}{|c|}{ Truncated regression } \\
\hline & & $\begin{array}{l}\text { Coefficients } \\
\text { (Robust } \\
\text { errors) }\end{array}$ & std. & $\begin{array}{l}\text { Average } \\
\text { marginal } \\
\text { effects }\end{array}$ & $\begin{array}{l}\text { Coefficient } \\
\text { (Robust } \\
\text { std.error) }\end{array}$ & $\begin{array}{l}\text { Average } \\
\text { marginal } \\
\text { effects }\end{array}$ \\
\hline \multicolumn{7}{|l|}{ Perceptions on farm forestry } \\
\hline Agricultural crops & $\begin{array}{l}0.099 \\
(0.041)^{* *}\end{array}$ & $\begin{array}{l}1.371 \\
(0.732)^{*}\end{array}$ & & 0.134 & $\begin{array}{l}0.033 \\
(0.028)\end{array}$ & 0.033 \\
\hline Perceived returns & $\begin{array}{l}0.534 \\
(0.068)^{* * *}\end{array}$ & $\begin{array}{l}2.881 \\
(0.480)^{* * *}\end{array}$ & & 0.411 & $\begin{array}{l}-0.005 \\
(0.068)\end{array}$ & -0.005 \\
\hline Income & $\begin{array}{l}0.364 \\
(0.076)^{* * *}\end{array}$ & $\begin{array}{l}2.568 \\
(0.515)^{* * *}\end{array}$ & & 0.347 & $\begin{array}{l}0.035 \\
(0.044)\end{array}$ & 0.035 \\
\hline Landsize & $\begin{array}{l}-0.005 \\
(0.001)^{* * *}\end{array}$ & $\begin{array}{l}0.085 \\
(0.035)^{* *}\end{array}$ & & 0.004 & $\begin{array}{l}-0.007 \\
(0.002)^{* * *}\end{array}$ & -0.007 \\
\hline Age & $\begin{array}{l}-0.002 \\
(0.001)^{*}\end{array}$ & $\begin{array}{l}0.003 \\
(0.005)\end{array}$ & & 0.002 & $\begin{array}{l}-0.001 \\
(0.001)\end{array}$ & -0.001 \\
\hline Security of tenure & $\begin{array}{l}-0.146 \\
(0.091)\end{array}$ & $\begin{array}{l}-0.545 \\
(0.431)\end{array}$ & & -0.036 & $\begin{array}{l}-0.034 \\
(0.074)\end{array}$ & -0.034 \\
\hline Female headed & $\begin{array}{l}0.023 \\
(0.038)\end{array}$ & $\begin{array}{l}-0.210 \\
(0.228)\end{array}$ & & -0.011 & $\begin{array}{l}0.060 \\
(0.036)^{*}\end{array}$ & 0.060 \\
\hline Secondary & $\begin{array}{l}0.067 \\
(0.045)\end{array}$ & $\begin{array}{l}0.572 \\
(0.220)^{* * *}\end{array}$ & & 0.035 & $\begin{array}{l}-0.011 \\
(0.037)\end{array}$ & -0.011 \\
\hline Tertiary & $\begin{array}{l}0.041 \\
(0.070)\end{array}$ & $\begin{array}{l}0.298 \\
(0.353)\end{array}$ & & 0.016 & $\begin{array}{l}0.002 \\
(0.052)\end{array}$ & 0.002 \\
\hline Forestry skills & $\begin{array}{l}0.132 \\
(0.048)^{* * *}\end{array}$ & $\begin{array}{l}0.580 \\
(0.185)^{* * *}\end{array}$ & & 0.038 & $\begin{array}{l}-0.002 \\
(0.040)\end{array}$ & -0.002 \\
\hline Experience & $\begin{array}{l}0.003 \\
(0.001)^{*}\end{array}$ & $\begin{array}{l}-0.007 \\
(0.005)\end{array}$ & & -0.000 & $\begin{array}{l}-0.000 \\
(0.001)\end{array}$ & 0.000 \\
\hline
\end{tabular}




\begin{tabular}{|c|c|c|c|c|c|}
\hline \multirow[t]{2}{*}{ Extension } & 0.117 & 0.526 & 0.030 & 0.060 & 0.060 \\
\hline & $(0.043)^{* * *}$ & $(0.251)^{* *}$ & & $(0.043)$ & \\
\hline \multirow[t]{2}{*}{ Employment } & 0.038 & 0.085 & 0.004 & 0.021 & 0.021 \\
\hline & $(0.079)$ & $(0.355)$ & & $(0.062)$ & \\
\hline \multirow[t]{2}{*}{ Log non-farm } & -0.001 & 0.002 & 0.001 & -0.000 & 0.000 \\
\hline & $(0.006)$ & $(0.026)$ & & $(0.005)$ & \\
\hline \multirow[t]{2}{*}{ Distance } & 0.020 & 0.011 & 0.000 & 0.019 & 0.019 \\
\hline & $(0.012)^{*}$ & $(0.021)$ & & $(0.012)$ & \\
\hline \multirow[t]{2}{*}{ Constant } & -0.371 & -2.058 & & 0.555 & \\
\hline & $(0.145)$ & $(0.575)^{* * *}$ & & $(0.109)^{* * *}$ & \\
\hline Number of observations & 839 & 839 & & 486 & \\
\hline Log likelihood & -351 & -76.6 & & -132 & \\
\hline Chi-square & $37.45^{* * *}$ & & & & \\
\hline Wald chi-square & & $107 * * *$ & & $27.93 * *$ & \\
\hline Mean VIF & & 1.99 & & 1.65 & \\
\hline
\end{tabular}

Results from the double-hurdle model (Table 2) show that the perceived returns from farm forestry investments, the perceived compatibility of on-farm plantation forestry with agricultural crop production and the perceived ability to provide out of crop season income significantly influenced the probability of adoption but did not influence the intensity decision once the adoption decision had been made. Farmers who rated the perceived compatibility with agricultural crop production, the perceived returns from investment and perceived ability to provide out of crop season income as positive attributes of on-farm plantation, on average, had a higher predicted probability of $0.13,0.40$ and 0.35 respectively, for adopting farm forestry than those who rated them negatively. The results also indicate that land size, secondary school education, forestry skills training and extension significantly explain the variation in the decision to invest in on-farm plantation forestry. On average, farmers who received forestry skills training and those who had received atleast one extension visit in the last year were 3.8 and 3.0 percentage points respectively, more likely to adopt on-farm plantation forestry than those who didn't receive these services. Similarly, farmers with secondary school education were, on average, 3.5 percentage points more likely to adopt than those with primary education.

The marginal effects indicate that female headed households had a higher proportion of farm land allocated to farm forestry by 0.06 compared to male headed households. The marginal effects also show that for an additional acre of land, the proportion of farm land allocated to farm forestry reduces by 0.007 .

The influence of education on adoption has been reported in other study findings. Attaining secondary education may enhance the ability to process technical information about new technologies and thereby facilitate adoption (Freeman \& Omiti, 2003; Jagger \& Pender, 2003; Adesina, 1996; Adesina et al., 2000).

The household landholding is also an important variable because having adequate land enables the household to diversify its cropping patterns into cash crops such as plantation forestry. Other studies have shown that, household endowments such as land holding are positively related to the probability of adopting new technologies (Doss, 2006; Freeman \& Omiti, 2003; Lunduka et al., 2012). This is because adoption of new technologies entails subjective risk, which smallholder farmers may not be willing to undertake since they have fewer resources to fall back on (Doss, 2006; Feder et al., 1985). However, land holding has a negative and significant influence on the intensity of adoption. This implies that the proportion of land allocated to farm forestry decreases with increase in landholding. This may also be explained by the hypothesis that farm forestry is mainly used to provide wood products for home consumption and a safety net during tough times such as out of crop season income and other emergencies (Angelsen \& Wunder, 2003). Therefore, farmers establish just enough acreage of on-farm plantation forestry to meet those needs.

The positive and significant influence of extension services on adoption of farm forestry agrees with findings of earlier studies (Alene et al., 2000; Idrisa et al., 2012; Staal et al., 2002). Access to extension services and formal skills training, provide farmers with information about plantation forestry technologies before they make a 
decision on adoption (Alene et al., 2000). Public extension service agents, NGO agents and mass media have been the main pathways for introducing on-farm plantation forestry to small-scale farmers in Uganda. The significance of the perception variables indicates that farmers are concerned about the returns, out of crop season income and compatibility of tree farming with agricultural crop production. This suggests that extension service agents should consider these attributes of farm forestry when designing adoption strategies. This also implies that forestry research should focus on enhancing these attributes of farm forestry to increase adoption.

\section{Conclusions and Recommendations}

This paper makes two main contributions. First, it identifies the factors influencing adoption and intensity of adoption of on-farm plantation forestry. The study confirmed the importance of farmers' access to extension services, landholding, education, forestry skills training and farmers' perceptions in adopting on-farm plantation forestry. This highlights some of the areas that should be considered in developing adoption strategies for on-farm plantation forestry. The study suggests that policy makers need to strengthen the capacity of forestry agencies to deliver extension services and formal forestry skills training in order to improve the adoption rate. The study also highlights the importance of farmers' perceptions in influencing adoption of farm forestry. This suggests that extension service providers should seek and consider farmers' perceptions of farm forestry technologies when developing their adoption strategies.

Second, the paper shows that the double-hurdle model is a better specification of the factors influencing adoption and intensity of adoption of farm forestry technologies than the standard Tobit. This implies that decision on whether to participate in farm forestry and the intensity of participation are made separately. Given that the factors influencing adoption and intensity of farm forestry adoption are different, it is important that both stages are considered in developing adoption strategies for farm forestry.

\section{Acknowledgements}

The authors are grateful to the National Agricultural Research Organisation (NARO) and the National Forestry Resources Research institute (NaFORRI) for providing the financial resources required for this study. The authors are also grateful to the staff of the department Of Agricultural And Applied Economics, Faculty Of Development Studies, Lilongwe Univeristy Of Agriculture And Natural Resources, Malawi.

\section{References}

Adesina, A. A. (1996). Factors affecting the adoption of fertilizers by rice farmers in Cote d'Ivoire. Nutrient Cycling Agroecosystems, 46, 29-39. http://dx.doi.org/10.1007/BF00210222

Adesina, A., \& Baidu-Forson, J. (1995). Farmers' perception and adoption of new agricultural technology: Evidence from analysis in Burkina Faso and Guinea, West Africa. Agricultural Economics, 13, 1-9. http://dx.doi.org/10.1016/0169-5150(95)01142-8

Adesina, A., Mbila, D., Nkamleu, B., \& Endamana, D. (2000). Econometric analysis of the determinants of adoption of alley farming by farmers in the forest zone of Southwest Cameroon. Agriculture, Ecosystem and Environment, 80(3), 255-256. http://dx.doi.org/10.1016/S0167-8809(00)00152-3

Alene, A. D., Poonyth, D., \& Hassan, R. M. (2000). Determinants of adoption and intensity of use of improved maize varieties in the central highlands of Ethiopia. A Tobit analysis. Agrekon, 39(4). http://dx.doi.org/10.1080/03031853.2000.9523679

Angelsen, A., \& Wunder, S. (2003). Exploring the forest-poverty link: Key concepts, issues and research implications. Center for International Forestry Research, occassional paper No. 40.

Bayard, B., Jolly, M. C., \& Shannon, D. A. (2007). The economics of adoption and management of alley $\begin{array}{llll}\text { cropping in Haiti. Journal of Environmental Management, } & \text { 84(1), }\end{array}$ http://dx.doi.org/10.1016/j.jenvman.2006.05.001

Buyinza, M., Banana, A. Y., Nabanoga, G., \& Ntakimye, A. (2008). Socio-economic determinants of farmers adoption of rotational woodlot technology in Kigorobya subcounty, Hoima district, Uganda. South African Journal of Agricultural Extension, 37.

Carroll, J., Mccarthy, S., \& Newman, C. (2005). An econometric analysis of charitable donations in the republic of Ireland. The Economic and Social Review, 36(3), 229-249.

Cragg, J. G. (1971). Some statistical models for limited dependent variable with application to the demand for durable goods. Econometrica, 39, 829-844. http://dx.doi.org/10.2307/1909582

Doss, C. R. (2006). Analysing technology adoption using microstudies: Limitations, challenges and 
opportunities for improvement. Agricultural Economics, $207-219$. http://dx.doi.org/10.1111/j.1574-0864.2006.00119.x

Feder, G., Just, R. E., \& Zilberman, D. (1985). Adoption of agricultural innovations in developing countries: A survey. Economic Development and Cultural Change, 33(2), 255-98. http://dx.doi.org/10.1086/451461

Fennema. J., \& Sinning, M. (2007). Double-hurdle models with dependent errors and heteroscedasticity. Retrived December 1, 2015, from. www.atususers.umd.edu/wip2/papers_i2007/wodajo.pdf

Freeman, A. H., \& Omiti, J. M. (2003). Fertilizer use in semi-arid areas of Kenya: Analysis of farmers' adoption behaviour under liberalized markets. Agro-ecosystems, 66, 23-31.

Greene, W. H. (2000). Econometric Analysis (4th ed.). N.J.: Prentice Hall, Englewood Cliffs.

Idrisa, Y. L., Ogunbameru, B. O., \& Madukwe, M. C. (2012). Logit and Tobit analyses of the determinants of likelihood of adoption of improved soybean seed in Borno state, Nigeria. Greener Journal of Agricultural Sciences, 2(2), 37-45.

Jagger, P., \& Pender, J. (2003). Impacts of programs and organizations on the adoption of sustainable land management technologies in Uganda. Washington, D.C: International Food Policy Research Institute (IFPRI).

Kaboggoza, J. (2011). Forest plantations and woodlots in Uganda. Retrived November 24, 2015, from www.afforum.org/sites/default/files/English/English_17.pdf

Katchova, A. L., \& Miranda, M. J. (2004). Two-step econometric estimation of farm characteristics affecting marketing contract decisions. American Journal of Agricultural Economics, 86(1), 88-102. http://dx.doi.org/10.1111/j.0092-5853.2004.00564.x

Lin, T., \& Schmidt, P. (1984). A test of Tobit specification against an alternative suggested by Cragg. Review of Economics and Statistics, 66(1). http://dx.doi.org/10.2307/1924712

Lunduka, R., Fisher, M., \& Snapp, S. (2012). Could farmer interest in diversity of seed attributes explain adoption plateaus for modern maize varieties in Malawi? Food Policy, (37), 504-510. http://dx.doi.org/10.1016/j.foodpol.2012.05.001

Martínez-Espiñeira, R. (2006). A box-cox Double-hurdle model of wildlife valuation: The citizen's perspective. Ecological Economics, 58(1), 192-208. http://dx.doi.org/10.1016/j.ecolecon.2005.07.006

MFPED(Ministry of Finance Planning and Economic Development). (2014). Poverty status report 2014: Kampala, MFPED.

Moffatt, P. G. (2003). Hurdle models of loan default. Retrieved from http://www.crc.ems.ed.ac.uk/ conference/presentations/moffat.pdf

MWLE (Ministry of Water, Lands and Environment). (2001). The national forest policy. Kampala: MWLE.

MWLE. (2002). The national forest plan. Kampala: MWLE.

Oeba, V. O., Otor, C. J., Kungu, J. B., \& Muchini, M. N. (2012). Modelling determinants of tree planting and retention on farm for improvement of tree cover in central Kenya. International Scholarly Research Network, 2012(867249), 14. http://dx.doi.org/10.5402/2012/867249

Olwande, J., Sikei, G., \& Mathenge, M. (2009). Agricultural technology adoption: A panel analysis of smallholder farmers' fertilizer use in Kenya. Paper presented at the African economic research consortium conference on agriculture for development, Mombasa, Kenya. Retrieved November 22 $2^{\text {nd }} 2015$, from https:/www.researchgate.net/publication/237718845_Agricultural_Technology_Adoption_A_Panel_Analys is_of_Smallholder_Farmers'_Fertilizer_use_in_Kenya.

Shiyani, R. L., Joshi, P. K., Asokam, M., \& Bantilan, M. C. S. (2002). Adoption of improved chickpea varieties: Krishak Bharati cooperative(KRIBHCO) experience in tribal region of Gujurat, India. Agricultural Economics, 27, 33-39. http://dx.doi.org/10.1111/j.1574-0862.2002.tb00102.x

SPGS (Sawlog Production Grant Scheme). (2005). Improving the investment environment for private sector plantation forestry development in Uganda. Kampala: SPGS.

Staal, S. J., Baltenkweck, I. L., Waithaka, M. M., De wolf, T., \& Njoroge, L. (2002). Location and uptake: Integrated household and GIS analysis of technology adoption and land use, with application to smallholder dairy farms in KENYA. Agricultural Economics, 27(3), $295-315$. http://dx.doi.org/10.1111/j.1574-0862.2002.tb00122.x 
Thirtle, C., Beyers, L., Ismael, Y., \& Piesse, J. (2003). Can GM-technologies help the poor? The impact of Bt cotton in Makhathini flats, KwaZulu-Natal. World Development, 31(4), 717-732. http://dx.doi.org/10.1016/S0305-750X(03)00004-4

Tiwari, K. R., Sitaula, K. B., Nyborg, I. P., \& Paudel, S. G. (2008). Determinants of farmers adoption of improved soil conservation technology in a middle mountain watershed of central Nepal. Environmental Management, 42, 210-222. http://dx.doi.org/10.1007/s00267-008-9137-z

Tobin, J. (1958). Estimation of relationships for limited dependent variables. Econometrica, 26, 24-36. http://dx.doi.org/10.2307/1907382

Wabbi, J. B., Taylor, D. B., \& Kasenge, V. (2006). A limited dependent variable analysis of integrated pest management adoption in Uganda. Paper presented at the American agricultural association annual meeting, Long Beach, California.

\section{Copyrights}

Copyright for this article is retained by the author(s), with first publication rights granted to the journal.

This is an open-access article distributed under the terms and conditions of the Creative Commons Attribution license (http://creativecommons.org/licenses/by/3.0/). 